19. Kendrich JE, DeHaan SJ, Parke JD 1981 Regulation of blood flow to respiratory muscles during hypoxia and hypercapnia. Proc Soc Exp Biol Med 166:157

20. Kontos HA, Wei EP, Raper AJ, Patterson JL Jr 1977 Local mechanism of $\mathrm{CO}_{2}$ action on cat pial arterioles. Stroke 8:226

21. Matalon S, Nesarajah MS, Krasney JA, Farhi LE 1983 Effects of acute hypercapnia on the central and peripheral circulation of conscious sheep. J Appl Physiol Respir Environ Exercise Physiol 54:803

22. Melmed H, Molteni RA, Jones MD Jr, Sheldon RE, Makowski EL, Meschia G 1980 Effect of $\mathrm{PO}_{2}$ on fetal pulmonary blood flow. Abstract Presented to the Society for Gynecologic Investigation, Atlanta, GA,

23. Meschia G 1976 Physiology of transplacental diffusion. In: Wynn RM (ed) Obstetrics and Gynecology Annual. Appleton-Century-Crofts, Norwalk, CT, pp 21-38

24. Meschia G, Battaglia FC, Makowski EL, Droegemueller W 1969 Effects of varying umbilical blood $\mathrm{O}_{2}$ affinity on umbilical vein $\mathrm{PO}_{2}$. J Appl Physiol $26: 410$

25. Molteni RA, Jones MD, Jr, Simmons MA 1980 The effect of breathing on pulmonary blood flow in the sheep fetus. Pediatr Res 14:648

26. Molteni RA, Melmed MH, Sheldon RE, Jones MD Jr, Meschia G 1980 Induction of fetal breathing by metabolic acidemia and its effect on blood flow to the respiratory muscles. Am J Obstet Gynecol 136:609

27. Parker PE, Dabney JM, Scott JB, Haddy FJ 1975 Reflex vascular responses in kidney, ileum, and forelimb to carotid body stimulation. Am J Physiol 228:46

28. Peeters LLH, Sheldon RE, Jones MD Jr, Makowski EL, Meschia G 1979
Blood flow to fetal organs as a function of arterial oxygen content. Am $\mathbf{J}$ Obstet Gynecol 135:637

29. Radawski D, Dabney JM, Daugherty RM Jr, Haddy FJ, Scott JB 1972 Local effects of $\mathrm{CO}_{2}$ on vascular resistances and weight of the dog forelimb. Am J Physiol 222:439

30. Rosenberg AA, Jones MD Jr, Traystman RJ, Simmons MA, Molteni RA 1982 Response of cerebral blood flow to changes in $\mathrm{PCO}_{2}$ on fetal, newborn and adult sheep. Am J Physiol [Heart Circ Physiol 11] 242:H862

31. Rudolph AM, Yuan S 1966 Response of the pulmonary vasculature to hypoxia and $\mathrm{H}^{+}$ion concentration changes. J Clin Invest 45:399

32. Rutherford JD, Vatner SP 1978 Integrated carotid chemorecepter and pulmonary inflation reflex control of peripheral vasoactivity in conscious dogs. Circ Res 43:200

33. Wallenstein S, Zucker CL, Fleiss JL 1980 Some statistical methods useful in circulation research. Circ Res 47:1

34. Woods JR Jr, Dandavino A, Murayama K, Brinkman CR III, Assali NS 1977 Autonomic control of cardiovascular functions during neonatal development and in adult sheep. Circ Res 40:401

35. Correspondence should be addressed to Adam A. Rosenberg, M.D., Division of Perinatal Medicine, CMSC 210, The Johns Hopkins Hospital, 600 North Wolfe Street, Baltimore, Md 21205.

36. The work was supported in part by The Hospital for Consumptives of Maryland (Eudowood) and by National Institutes of Health Research Grant HD13830.

37. Received for publication November 29, 1983.

\title{
Diabetes in Pregnancy: Decreased Placental Blood Flow and Disturbed Fetal Development in the Rat
}

\author{
ULF J. ERIKSSON ${ }^{(37)}$ AND LEIF JANSSON \\ Department of Medical Cell Biology, University of Uppsala, Uppsala, Sweden
}

\section{Summary}

Placental blood flow was measured with the aid of radioactive microspheres, in normal (N) and manifest diabetic (MD) rats, and related to fetal body growth and incidence of congenital malformations. The total blood flow in the placentae of the MD rats was decreased to about one-half of the normal flow on gestational days 20 and 22. The placentae of the MD offspring were enlarged, whereas the fetuses in this group were smaller than normal. Thus, the placental blood flow per placental weight was drastically decreased in the MD fetuses on both days 20 and 22. In contrast, the placental blood flow per fetal weight was not different in the $N$ and MD groups on gestational day 20 whereas it was decreased in the MD offspring on gestational day 22 . Placental blood flow in the malformed fetuses of the MD group did not differ significantly from that in the nonmalformed MD fetuses.

\section{Abbreviations}

$N$, normal control rat (nondiabetic)

N20 or N22, normal pregnant rat on gestational day 20 or 22

MD, manifest diabetic rat (serum glucose level exceeding 20 $\mathrm{mmol} / \mathrm{liter}$ )

MD20 or MD22, pregnant manifest diabetic rat on gestational day 20 or 22
The etiology of altered fetal development defined as increased/ decreased fetal weight, malformations, and an increased number of resorptions in the diabetic pregnancy is at present not clear (23). Disturbances in the transfer of nutrients from mother to fetus, reflecting altered placental function, may be of importance for the decreased somatic growth rate $(17,18)$. Besides, the magnitude of the placental blood flow determines the amount of nutrients available for transfer to the fetus (27). Therefore, placental blood flow may be relevant to fetal growth retardation (28). Decreased placental blood supply has been accomplished experimentally in rats subjected to uterine artery ligation (21) and maternal dietary restriction (29). The offspring of these rats show decreased fetal weights and increased number of intrauterine resorptions.

Although a number of estimations of placental blood flow in rodents have been reported $(1,2,5,7,15,16,27,29,34)$, no studies of placental blood flow in diabetic rat pregnancy seem to have been published. There are, however, reports of altered placental morphology (26) and indirect evidences of changed vascular function in diabetic rat placenta (4) as well as decreased transfer of aminoisobutyric acid to fetuses of diabetic guinea pigs (30). Also, reduced uteroplacental blood flow as determined with placental scintigraphy has recently been demonstrated in human diabetic pregnancy (19).

The aim of the present study was to examine the relation 
between uteroplacental blood flow and fetal somatic growth in normal and diabetic rat pregnancy. In addition, fetuses of a rat model that showed a recognized type of congenital malformation $(9,10)$ were specially studied in order to evaluate whether the placental blood flow of the malformed fetuses differed from that of their nonmalformed littermates.

\section{MATERIALS AND METHODS}

A total number of 24 female virgin Sprague-Dawley rats (Anticimex AB, Sollentuna, Sweden), weighing 240-260 g, were made diabetic by a single IV injection of streptozotocin (kindly donated by Dr. W. E. Dulin, The Upjohn Co., Kalamazoo, MI) in a dose of $45-50 \mathrm{mg} / \mathrm{kg}$ body weight. One week later, the blood glucose concentration of each animal was measured by means of a Beckman glucose analyzer model 2 (Beckman Inc., Fullerton, CA). Animals with serum glucose levels exceeding $20 \mathrm{mmol} /$ liter were subsequently denoted MD ( $c f$. Ref. 8). Fifteen weightand age-matched female rats served as controls $(\mathrm{N})$ and did not receive any injections at all. The rats were kept in a light- and temperature-controlled environment with $12+12$-h light-dark cycle and were fed standard rat pellets (Ewos AB, Södertälje, Sweden) and tap water ad libitum. Mating of the animals was started 10-14 days after the streptozotocin injection. Two or three female rats were mated with nondiabetic male rats overnight and conception was confirmed by examination of vaginal smears for the presence of sperm in the morning. The day when a positive vaginal smear was obtained was denoted gestational day 0 ; the rats of this strain normally deliver in the early afternoon of gestational day 22. Studies of the offspring were performed on gestational days 20 and 22 .

In the morning of day 20 or 22 the pregnant rats were weighed and anesthetized with thiobutabarbital sodium (Inactin, BykGulden, Konstanz, Germany) given in an IP dose of $120 \mathrm{mg} / \mathrm{kg}$ body weight. Polyethylene catheters were inserted into the left ventricle of the heart (via the right carotid artery) and into the left femoral artery. ${ }^{103} \mathrm{Ru}$-labeled microspheres (New England Nuclear Chemicals $\mathrm{GmbH}$, Dreieich, Germany) with a diameter of $15.5 \pm 1.1 \mu \mathrm{m}$ (mean \pm SD) were suspended in $0.4 \mathrm{ml}$ of physiological saline containing $0.01 \%$ Tween 80 . This solution was carefully mixed with the aid of a whirl mixer for at least 10 min and $0.2 \mathrm{ml}$ (containing approximately 150,000 microspheres) was injected via the carotid catheter in $20 \mathrm{sec}$. A reference sample was withdrawn simultaneously from the femoral artery at a constant rate $(0.67 \mathrm{ml} / \mathrm{min})$ during $90 \mathrm{sec}$. Arterial blood pressure and body temperature of the pregnant rats were monitored during the experiment and in all cases found to be well within normal limits. The animals were subsequently killed by cervical dislocation, a blood sample was secured for determination of serum glucose, and the position of the cardiac catheter was controlled at the autopsy.

The uterus was quickly mobilized through a midline incision and each fetus and placenta were carefully dissected free of surrounding tissue, inspected, and weighed. A fetus was considered to be malformed if it lacked a tail or showed visible retardation of the mandible (micrognathia; $c f$. Refs. 9 and 10). Three to six placentae from nonmalformed fetuses per uterine horn were chosen at random, blotted, weighed, and freeze-dried to constant weight in a GT 2 freeze drier (Leybold-Heraeus AG, West Germany) for 24-48 h together with placentae belonging to malformed fetuses. In addition, the kidneys and the lower right lung lobe of the rat mothers were dissected out, weighed, and freeze-dried in order to control adequate mixing and the degree of shunting of the microspheres through peripheral circulatory beds. To estimate the transfer of spheres across the placental barrier, a few fetuses were also processed in the same way.

After the freeze-drying procedure, the content of radioactivity in the different tissues was measured in a LKB-Wallac 80,000 gamma counter (Wallac OY, Turku, Finland) and the blood flow of each placenta was calculated with the aid of the following formula: $Q_{\text {plac }}=\left(R_{\text {plac }} \times Q_{\text {ref }}\right) / R_{\text {ref }}$ where $Q_{\text {plac }}, Q_{\text {ref, }}$ and $R_{\text {plac }}, R_{\text {ref }}$ denote the flow $(Q \mathrm{ml} / \mathrm{min})$ and radioactivity $(R \mathrm{cpm})$ of the placenta (plac) and reference (ref) samples, respectively. The blood flows were then correlated to both the wet and dry weight of the placentae, as well as to the fetal weights. Since each uterine horn of the rat is mainly supplied by its uterine and ovarian artery and only to a small extent by minor anastomotic branches from the vaginal branch of the hypogastric artery, each uterine horn was considered as a separate circulatory unit. Therefore, when comparing the results from $\mathrm{N}$ and MD fetuses, the estimated mean value per horn of the different parameters was used. The blood flow of the maternal lungs and kidneys was determined in an analogous manner. Probabilities of chance differences between the means of different experimental groups were estimated by Student's two-tailed $t$ test (22).

\section{RESULTS}

Two of the $\mathrm{N}$ and seven of the MD rats did not become pregnant, despite 10-15 mating attempts during 4 weeks. Four of the pregnant MD rats had only resorptions and dead fetuses at the time of cesarian section and were therefore excluded. In one of the MD rats there were living fetuses in only one uterine horn; therefore, the MD22 group was comprised of seven rats in whom only 13 uterine horns could be examined ( $c f$. Table 1). Altogether, the $\mathrm{N}$ and MD mother rats with viable offspring contained 165 and 130 implantations of which 8 and 33 were resorbed, respectively. Of the viable $157 \mathrm{~N}$ fetuses and $97 \mathrm{MD}$ fetuses, no malformations were found in the $\mathrm{N}$ groups, whereas five fetuses in the MD groups showed either loss of the tail or micrognathia. These two types of skeletal malformations have been discussed previously $(9,10)$. The blood flow in the right and left maternal kidneys were $4.1 \pm 0.8$ and $4.3 \pm 0.8 \mathrm{ml} / \mathrm{min}$ . $\mathrm{g}$ wet weight in the $\mathrm{N} 20$ and $4.2 \pm 1.0$ and $4.3 \pm 1.3 \mathrm{ml} / \mathrm{min}$ - $g$ wet weight in the $\mathrm{N} 22$ groups. The MD rats showed a tendency towards lower values. Thus, the blood flow in the kidneys were $2.7 \pm 1.0$ and $3.0 \pm 0.8 \mathrm{ml} / \mathrm{min} \cdot \mathrm{g}$ wet weight in the MD20 group and $2.2 \pm 0.4$ and $2.5 \pm 0.6 \mathrm{ml} / \mathrm{min} \cdot \mathrm{g}$ wet weight in the MD22 group. Evidently, no difference could be demonstrated between the blood flow in the kidneys on the different sides in the $\mathrm{N}$ and MD groups, thereby illustrating adequate mixing of the microspheres. The MD maternal kidneys were enlarged in comparison to the $\mathrm{N}$ mothers (N20: $0.92 \pm$ $0.04 \mathrm{~g}$; MD20: $1.49 \pm 0.04 \mathrm{~g} ; P<0.001 ; \mathrm{N} 22: 0.86 \pm 0.07 \mathrm{~g}$; MD22: $1.42 \pm 0.06 \mathrm{~g} ; P<0.001)$. The estimated blood flows through the maternal lungs were $0.8 \pm 0.3$ and $0.5 \pm 0.4 \mathrm{ml} /$ min $\cdot g$ wet weight in the $\mathrm{N} 20$ and $\mathrm{N} 22$ groups and $0.5 \pm 0.2$ and $0.6 \pm 0.3 \mathrm{ml} / \mathrm{min} \cdot \mathrm{g}$ wet weight in the MD20 and MD22 groups, respectively. These low values illustrate the low peripheral shunt rate of microspheres in the pregnant animals. In addition, there was no detectable radioactivity in any of the fetuses that were processed along with the placental and other

Table 1. Body weight and serum glucose concentration of $N$ and MD pregnant rats on gestational days 20 and $22^{*}$

\begin{tabular}{|c|c|c|c|c|c|}
\hline Group & $\begin{array}{l}\text { No. } \\
\text { of rats }\end{array}$ & $\begin{array}{c}\text { Maternal } \\
\text { body weight } \\
\text { (g) }\end{array}$ & $\begin{array}{l}\text { Maternal } \\
\text { serum glu- } \\
\text { cose concen- } \\
\text { tration } \\
(\mathrm{mg} / \mathrm{dl})\end{array}$ & $\begin{array}{l}\text { No. of } \\
\text { uterine } \\
\text { horns }\end{array}$ & $\begin{array}{l}\text { No. of viable } \\
\text { offspring } \\
\text { (per horn) }\end{array}$ \\
\hline $\mathrm{N} 20$ & 7 & $384 \pm 8$ & $100 \pm 6$ & 14 & $5.2 \pm 0.5$ \\
\hline MD20 & 6 & $326 \pm 17 \dagger$ & $572 \pm 6 \ddagger$ & 12 & $3.9 \pm 0.7$ \\
\hline $\mathrm{N} 22$ & 6 & $434 \pm 9$ & $103 \pm 5$ & 12 & $7.0 \pm 0.5$ \\
\hline MD22 & 7 & $341 \pm 19 \ddagger$ & $547 \pm 39 \ddagger$ & 13 & $3.8 \pm 0.5 \neq$ \\
\hline
\end{tabular}

$*$ Values are means $\pm \mathrm{SE}$.

$\dagger P<0.01 v s$. $\mathrm{N}$ rats of the same age.

$\ddagger P<0.001$ vs. $\mathrm{N}$ rats of the same age. 
organ samples, indicating that no maternal blood corpuscles were transferred to the fetuses.

The maternal MD rats were severely hyperglycemic and weighed about 50 and $100 \mathrm{~g}$ less than the $\mathrm{N}$ rats on gestational days 20 and 22 , respectively (Table 1 ). On gestational day 20, there was no significant difference between the MD and normal groups with respect to number of viable offspring. On the other hand, on gestational day 22 , the MD rats showed a significantly decreased number of viable offspring per uterine horn (Table 1).

The MD offspring weighed less $(P<0.01)$ but had larger placentae than the $\mathrm{N}$ fetuses, both when the wet $(P<0.001)$ and dry $(P<0.01)$ weights of the placentae were compared (Table 2). The three malformed fetuses in the MD20 and the two malformed in the MD22 groups exhibited the same growth pattern as the other MD fetuses. Thus, their body weights $(2.0 \pm$ 0.3 and $4.7 \pm 0.3 \mathrm{~g}$ on gestational days 20 and 22 , respectively) as well as wet $(0.66 \pm 0.05$ and $0.67 \pm 0.09 \mathrm{~g})$ and dry $(0.111 \pm$ 0.002 and $0.113 \pm 0.016 \mathrm{~g}$ ) placental weights were not statistically different from the remaining MD offspring in the respective age groups. Furthermore, no differences were found between the percentage dry residue of the different placentae (Table 2).

The MD offspring showed decreased total blood flow $(P<$ $0.05)$ as well as decreased flow per wet $(P<0.001)$ and dry $(P<$ $0.001)$ placental weight compared to the normal offspring both on gestational days 20 and 22 (Table 3). This was true also for the malformed fetuses whose total blood flow $(0.22 \pm 0.07$ and $0.35 \pm 0.03 \mathrm{ml} / \mathrm{min})$ as well as blood flow per wet $(0.4 \pm 0.1$ and $0.5 \pm 0.1 \mathrm{ml} / \mathrm{min} \cdot \mathrm{g})$ and dry $(2.0 \pm 0.7$ and $3.2 \pm 0.7 \mathrm{ml} /$ min - g) placental weight were statistically similar to the nonmalformed MD fetuses. The $\mathrm{N}$ fetuses increased significantly their flow rates between days 20 and 22 in all three respects $(P$ $<0.01$ in all three comparisons), whereas the MD offspring failed to show any significant differences between gestational days 20 and 22 with regard to these three parameters $(P>0.10$ in all three comparisons). The placental blood flow per fetal weight showed a different pattern. No differences between the $\mathrm{N}$ and MD groups were found on gestational day 20, whereas the MD22 flow was only about half of the N22 flow $(P<0.01$, Table 3$)$. The malformed MD fetuses did not differ significantly from the nonmalformed MD fetuses $(0.12 \pm 0.04 \mathrm{ml} / \mathrm{min} \cdot \mathrm{g}$ at gestational day 20 and $0.07 \pm 0.001 \mathrm{ml} / \mathrm{min}$ - fetal weight at gestational day 22).

\section{DISCUSSION}

The use of radioactive microspheres for estimating organ blood flow in the rat is a widely accepted and thoroughly evaluated experimental procedure $(14,20,31)$. The blood flow per placenta of the $\mathrm{N}$ fetuses, $0.50-0.95 \mathrm{ml} / \mathrm{min}$, was in the range of previously reported flow rates of rats in late gestation $(2,3,5,15,16,21$, $29,34)$. Also, our values of renal blood flow and pulmonary blood flow are in agreement with those found in previous investigations $(20,31)$. Thus, the applied method appears well suited

Table 2. Body weight and wet and dry placental weights of the offspring of $N$ and $M D$ rat mothers on gestational days 20 and $22^{*}$

\begin{tabular}{lccccc}
\hline Group & $n$ & $\begin{array}{c}\text { Fetal } \\
\text { body weight } \\
(\mathrm{g})\end{array}$ & $\begin{array}{c}\text { Placental } \\
\text { wet weight } \\
(\mathrm{g})\end{array}$ & $\begin{array}{c}\text { Placental } \\
\text { dry weight } \\
(\mathrm{g})\end{array}$ & $\begin{array}{c}\text { Dry residue } \\
(\%)\end{array}$ \\
\hline $\mathrm{N} 20$ & 14 & $4.0 \pm 0.1$ & $0.47 \pm 0.01$ & $0.070 \pm 0.003$ & $15.1 \pm 0.4$ \\
$\mathrm{MD} 20$ & 12 & $2.6 \pm 0.2 \dagger$ & $0.76 \pm 0.03 \dagger$ & $0.121 \pm 0.006 \dagger$ & $16.0 \pm 0.4$ \\
& & & & & \\
$\mathrm{~N} 22$ & 12 & $6.4 \pm 0.1$ & $0.44 \pm 0.02$ & $0.076 \pm 0.007$ & $17.0 \pm 1.1$ \\
$\mathrm{MD} 22$ & 13 & $5.0 \pm 0.4 \ddagger$ & $0.64 \pm 0.04 \dagger$ & $0.108 \pm 0.006 \ddagger$ & $17.1 \pm 0.7$ \\
\hline
\end{tabular}

$*$ Values are means $\pm \mathrm{SE}$, and $n$ denotes the number of uterine horns examined.

$\dagger P<0.001 v s$. $\mathrm{N}$ fetuses of the same age.

$\ddagger P<0.01 v$ v. $\mathrm{N}$ fetuses of the same age.
Table 3. Placental blood flow of the offspring of $N$ and MD rat mothers on gestational days 20 and $22 *$

\begin{tabular}{lccccc}
\hline Group & $n$ & $\begin{array}{c}\text { Blood flow/ } \\
\text { placenta } \\
(\mathrm{ml} / \mathrm{min})\end{array}$ & $\begin{array}{c}\text { Blood } \\
\text { flow/wet } \\
\text { weight } \\
(\mathrm{ml} / \mathrm{min} \cdot \mathrm{g})\end{array}$ & $\begin{array}{c}\text { Blood } \\
\text { flow/dry } \\
\text { weight } \\
(\mathrm{ml} / \mathrm{min} \cdot \mathrm{g})\end{array}$ & $\begin{array}{c}\text { Blood flow/ } \\
\text { fetal weight } \\
(\mathrm{ml} / \mathrm{min} \cdot \mathrm{g})\end{array}$ \\
\hline N20 & 14 & $0.50 \pm 0.05$ & $1.1 \pm 0.1$ & $7.2 \pm 0.8$ & $0.13 \pm 0.01$ \\
MD20 & 12 & $0.33 \pm 0.06 \dagger$ & $0.4 \pm 0.1 \ddagger$ & $2.9 \pm 0.5 \ddagger$ & $0.14 \pm 0.02$ \\
& & & & & \\
N22 & 12 & $0.95 \pm 0.13$ & $2.1 \pm 0.3$ & $12.6 \pm 1.7$ & $0.15 \pm 0.02$ \\
MD22 & 13 & $0.40 \pm 0.06 \ddagger$ & $0.6 \pm 0.1 \ddagger$ & $3.8 \pm 0.6 \ddagger$ & $0.08 \pm 0.01 \S$ \\
\hline
\end{tabular}

* Values are means $\pm \mathrm{SE}$, and $n$ denotes the number of uterine horns examined.

$\dagger P<0.05$ vs. $\mathrm{N}$ fetuses of the same age.

$\S P<0.01$ vs. N fetuses of the same age.

$\ddagger P<0.001 v s$. $\mathrm{N}$ fetuses of the same age.

for the investigation of placental blood flow during normal and pathological conditions.

The main finding in this study was the drastic reduction in placental blood flow in the MD offspring. The simultaneously occurring increase in placental weight suggests a long-term compensatory mechanism, aiming to secure a sufficient nutrient supply to the fetus. The exact nature of the increased weight of the MD placentae is at present obscure, but it has been shown that the DNA content of the placenta is increased in severe diabetes in humans and rats $(6,33)$, concomitant with increased levels of glycogen $(12,13)$ and triglycerides $(6)$. Interestingly, in other experimental studies, the combination of decreased fetal and increased placental weights is also encountered in the offspring of alcohol-treated rats (15), whereas uterine artery ligation or caloric deprivation decreases placental and fetal weights $(21$, 29).

In the $\mathrm{N}$ rats, the placental blood flow increased between gestational days 20 and 22 , yielding similar ratios of placental flow per fetal weight on the 2 days. This was in obvious contrast to the MD rats, in which no such increase in placental blood supply occurred during the period. The data suggest a failing capacity in the MD placentae to respond to increased metabolic and nutritional needs in late gestation.

Previous studies have shown decreased fetal weights and increased numbers of fetal resorptions and malformations in the MD offspring (8-11). There is evidence in favor of an analogous situation in early human diabetic pregnancy. Ultrasound determinations have indicated decreased fetal somatic growth in the 7th to 14th week of gestation (24); these studies also suggest that the risk for a malformed fetus in the diabetic pregnancy may increase with increasing degree of fetal body growth retardation (25). The notion of an interdependence between lowered somatic growth and increased rate of malformations in the human fetus has also been recently supported by a retrospective analysis of epidemiological data (32). The rat model in the present study may therefore primarily serve as a model for embryological and fetal growth in early human pregnancy.

It is tempting to relate the decreased blood flow in the MD placentae in the present study to the previously demonstrated growth retardation in the MD fetuses (8-11). In this context, the reported association between lowered maternal weight gain, decreased fetal birth weight, and decreased placental blood flow during maternal malnutrition (28) may be of importance. Our limited understanding of the exact etiology behind the retarded maternal weight gain in the MD group, however, makes clearcut comparisons difficult. For instance, the recently reported zinc deficiency of the MD fetuses may also contribute to the fetal growth retardation in the MD group (11). It may be that alterations in other essential nutrients play important roles for the induction of the fetomaternal growth retardation in the MD pregnancy.

Since there were no differences in the blood supply to the 
placentae of the malformed MD offspring in comparison with the nonmalformed MD fetuses, the induction of fetal malformations in diabetic rat pregnancy seems not to involve any restriction of nutrient transfer via the chorioallantoic placenta. Alternatively, the teratological processes inducing skeletal malformations in this diabetic rat model do not seem to hamper placental blood supply. The distorted fetal growth in this rat model may allow further experimental studies of the mechanisms causing abnormal fetal development in early human diabetic pregnancy.

\section{REFERENCES AND NOTES}

1. Bjellin L, Sjöquist P-OB, Carter AM 1975 Uterine, maternal placental and ovarian blood flow throughout pregnancy in the guinea pig. Z Geburtsh Perinatol 179:179

2. Bruce NW: The distribution of blood flow to the reproductive organs of rats near term. J Reprod Fertil 46:359

3. Buelke-Sam J, Nelson CJ, Byrd RA, Holson JF 1982 Blood flow during pregnancy in the rat. I. Flow pattern to maternal organs. Teratology 26:269

4. Clabaut M, Cougnaud A, Schrub JC 1982 Effet d'un vasodilatateur sur la croissance foetoplacentaire chez la ratte gestante diabetique. J Pharmacol (Paris) 13:253

5. Csepli J, Menyhart J, Lengyel S, Bodnar J, Turoczi F 1968 Blood circulation in pregnant rats. II. Some features of uterine circulation during pregnancy. Acta Chir Acad Sci Hung Tomus 9:143

6. Diamant YZ, Metzger BE, Freinkel N, Shafir E 1982 Placental lipid and glycogen content in human and experimental diabetes mellitus. Am J Obstet Gynecol 144:5

7. Duncan SLB 1969 The partition of uterine blood flow in the pregnant rabbit. J Physiol 204:421

8. Eriksson UJ, Andersson A, Efendic S, Elde R, Hellerström, C 1980 Diabetes in pregnancy: effects on the fetal and newborn rat with particular regard to body weight, serum insulin concentration and pancreatic contents of insulin, glucagon and somatostatin. Acta Endocrinol (Copenh.) 94:354

9. Eriksson UJ, Dahlström E, Larsson KS, Hellerström C 1982 Increased incidence of congenital malformations in the offspring of diabetic rats and their prevention by maternal insulin therapy. Diabetes 31:1

10. Eriksson UJ, Dahlström E, Hellerström C 1983 Diabetes in pregnancy: skeletal malformations in the offspring of diabetic rats after intermittent withdrawal of insulin in early gestation. Diabetes, 32:1141

11. Eriksson UJ 1984 Diabetes in pregnancy: retarded fetal growth, congenital malformations and fetomaternal concentrations of zinc, copper and manganese in the rat. $J$ Nutr 114:477

12. Hagerman DD 1962 Metabolism of tissues from pregnant diabetic rats in vitro. Endocrinology 70:88

13. Heijkenskjöld F, Gemzell C 1957 Glycogen content in the placenta of diabetic mothers. Acta Pediatr Scand 46:74

14. Ishise S, Pegrum BL, Yamamoto J, Kitamara J, Frohlich ED 1980 Reference sample microsphere method: cardiac output and blood flow in conscious rats. Am J Physiol 239:H443

15. Jones PJH, Leichter J, Lee M 1981 Placental blood flow in rats fed alcohol before and during gestation. Life Sci 29:1153
16. Karlsson K, Ljungblad U, Lundgren Y 1982 Blood flow of the reproductive system in renal hypertensive rats during pregnancy. Am J Obstet Gynecol 142:1039

17. Kim YS, Kim Y 1981 A new animal model for fetal macrosomia in diabetic pregnancy. Exp Mol Pathol 35:388

18. Krauer $\mathrm{F}$, Joyce J, Young $\mathrm{M} 1973$ The influence of high maternal plasma glucose levels, and maternal blood flow on the placental transfer of glucose in the guinea pig. Diabetologia 9:453

19. Lunell N-O, Joelsson I, Lewander R, Nylund L, Sarby B, Thornström S, Wager J 1982 Utero-placental blood flow and the effect of $\beta_{2}$-adrenoceptor stimulating drugs. Acta Obstet Gynecol Scand Suppl 108:25

20. Malik AB, Kaplan JE, Saba TM 1976 Reference sample method for cardiac output and regional blood flow determinations in the rat. J Appl Physiol 40:472

21. Nitzan M, Orloff S, Schulman JD 1979 Placental transfer of analogs of glucose and amino acids in experimental intrauterine growth retardation. Pediatr Res 13:100

22. Ostle B 1963 Statistics in Research, 2nd ed. The Iowa State University Press, Ames, IA

23. Pedersen J 1977 The Pregnant Diabetic and Her Newborn, 2nd ed. Munksgaard, Copenhagen, pp 1-280

24. Pedersen JF, Mølsted-Pedersen L 1979 Early growth retardation in diabetic pregnancy. Br Med J 1:18

25. Pederson JF, Mølsted-Pedersen L 1982 Early growth delay predisposes the fetus in diabetic pregnancy to congenital malformation. Lancet 1:737

26. Prager R, Abramovici A, Liban E, Laron Z 1974 Histopathological changes in the placenta of streptozotocin induced diabetic rats. Diabetologia 10:89

27. Reynolds ML, Young M 1971 The transfer of free $\alpha$-amino nitrogen across the placental membrane in the guinea-pig. J Physiol 214:583

28. Rosso P 1981 Nutrition and maternal-fetal exchange. Am J Clin Nutr 34:744

29. Rosso P, Kawa R 1980 Effects of food restriction on cardiac output and blood flow to the uterus and placenta in the pregnant rat. $J$ Nutr 110:2350

30. Saintonge J, Coté R 1983 Intrauterine growth retardation and diabetic pregnancy: two types of fetal malnutrition. Am J Obstet Gynecol 146:194

31. Sasaki Y, Wagner HN Jr 1971 Measurement of the distribution of cardiac output in unanesthetized rats. J Appl Physiol 30:879

32. Spiers PS 1982 Does growth retardation predispose the fetus to congenital malformation? Lancet 1:312

33. Winick M, Noble A 1967 Cellular growth in human placenta. II. Diabetes mellitus. J Pediatr 71:216

34. Yamaguchi R, Shintani M, Ishibashi S, Ushioda E, Nishikawa Y 1979 Uteroplacental blood flow and uteroplacental shunt rates in normal and prolonged pregnancies in rats. Tohoku J Exp Med 127:389

35. The expert technical assistance of Elisabet Wennberg, Astrid Nordin, Eva Törnelius, Ann-Mari Wencker, and Parri Wentzel is gratefully acknowledged.

36. The radioactive micospheres were a generous gift from Prof. A. Bill, Department of Physiology, Uppsala University, Uppsala, Sweden.

37. Requests for reprints should be addressed to: Dr. Ulf J. Eriksson, Department of Medical Cell Biology, Biomedicum, P.O. Box 571, S-751 23 Uppsala, Sweden.

38. This investigation was supported by the Swedish Medical Research Council (12X-109, a Post-Doctoral Fellowship K82-12P-6346-01 to Dr. Eriksson), the "Expressen" Prenatal Research Foundation. The Medical Faculty of the University of Uppsala, The Swedish Diabetes Association and the Nordic Insulin Fund.

39. Received for publication December 2, 1983. 